\title{
NEW AND ADDITIONAL RECORDS OF RARE FISH SPECIES FROM THE ANATOLIAN COASTS OF TURKEY
}

Sercan YAPICI, Faculty of Fisheries, Muğla Sıtkı Koçman University/Turkey, sercanyapici@mu.edu.tr (iD) https://orcid.org/0000-0003-2288-5084)

Received: 11.12.2018, Accepted: 18.02.2019

*Corresponding author

Research Article

DOI: $10.22531 /$ muglajsci.481750

\section{Abstract \\ In this study, rare fish species observed from underwater observation and amateur fishing activities in the Aegean and the Mediterranean coasts have been reported. New and additional records belonging to four fish species were represented: Mola mola and Ranzania laevis were observed from the Aegean and Levant Sea after decades while juvenile Trachipterus trachypterus and Lophotus lacepede were reported firstly in Turkish coasts of Aegean and Levant Sea, respectively. \\ Keywords: Rare species, Levant Sea, Aegean Sea, Biodiversity \\ TÜRKIYE ANADOLU KIYILARINDAN NADİR BALIK TÜRLERİNINN YENİ VE EK KAYITLARI}

\section{Özet}

Bu çalışmada, Ege ve Akdeniz kıyılarında sualtı gözlemi ve amatör balıkçılık faaliyetlerinde gözlenen nadir balık türleri rapor edilmiștir. Dört balı türüne ait yeni ve ek kayıtlar sunulmuștur: Mola mola ve Ranzania laevis yıllar sonra Ege ve Levant Denizinden gözlenirken, juvenil Trachipterus trachypterus ve Lophotus lacepede ilk kez sirasiyla Ege ve Levant Denizinin Türk klyılarından rapor edilmiştir.

Anahtar Kelimeler: Nadir tür, Levant Denizi, Ege Denizi, Biyo-çeșitlilik

Cite

YapIcI, S., (2019). "NEW AND ADDITIONAL RECORDS OF RARE FISH SPECIES FROM THE ANATOLIAN COASTS OF TURKEY”, Mugla Journal of Science and Technology, 5(1), 13-16.

\section{Introduction}

Structural changes in marine communities occurred naturally over geological times. Nowadays, anthropogenic effects that are more destructive than natural changes, however, could alter geographical distribution of plant and animal species. Global warming, one of the most pressing environmental issue, originated from these anthropogenic effects, cause to accelerate the shift and poleward migration of many taxa that are now extending their natural biogeographical range in the Mediterranean as well as worldwide. Some of the native and non-native species, typically known as thermophilic, are therefore currently colonizing the northern sectors. Azzurro [1, 2] categorized thermophilic fishes of the Mediterranean into two major groups: 1) Native or indigenous fishes, tropical or subtropical origin, entered in the Mediterranean during previous interglacial phases of the Quaternary. These species occur typically in the southern Mediterranean, where the water temperature is warmer than average. The northward range expansion of the native thermophilic biota has been termed as "meridionalization". 2) Exotic (or non-indigenous fishes), have recently entered the Mediterranean, mainly from the Red Sea or from the Atlantic Ocean. These species have the ability for dispersal in the western and eastern sectors of the Mediterranean. The increase of water temperature allows the successful introduction and then spreading of exotic tropical species in the Mediterranean Sea, a phenomenon that has been called 'tropicalization'. Another definition that has been used is "demediterraneization" [3] and represented the process of biotic homogenization of the Mediterranean Sea. To date, the marine fishes on the Turkish coasts currently consists of 512 species, including 4 classes: Actinopterygii (446 species), Elasmobranchii (64 species), Cephalaspidomorphi (1 species), Holocephali (1 species), 65 of these species have been reported as non-native species for Turkish coasts [4]. Based on underwater visual census and amateur fishing activities, the presence of Mola mola (Linnaeus, 1758), Ranzania laevis (Pennant, 1776), Trachipterus trachypterus (Gmelin, 1789) and Lophotus lacepede Giorna, 1809 from the Turkish coasts. The present study aims to improve our knowledge of the rare fish species of the Aegean Sea 
and the Mediterranean by reporting new and reoccurrence species in the ichthyofauna of the Turkish coasts to date.

\section{Material and Methods}

\subsection{Mola mola}

On 14 January 2017, a single specimen of Ocean sunfish was observed and photographed by a SCUBA diver in İbrice Cape $\left(40^{\circ} 3534^{\prime} \mathrm{N}, 26^{\circ} 3046^{\prime} \mathrm{E}\right)$ at a depth of $9 \mathrm{~m}$. The specimen was described using high-quality photos as in Golani et al. 2006 [5].

\subsection{Ranzania laevis}

On 11 April 2018, a single specimen of Slender sunfish was found as stranding on the beach by amateur fisherman from Karataş, Adana (36 $3427^{\prime} \mathrm{N}, 35^{\circ} 2406^{\prime}$ E). The specimen again was using high-quality photos as in Golani et al. 2006 [5].

\section{Trachipterus trachypterus}

On 02 February 2016, a juvenile specimen of Mediterranean dealfish was photographed and video recorded by native scientist from Çeşme coastline in Izmir $\left(38^{\circ} 1940^{\prime} \mathrm{N}, 2^{\circ} 1750^{\prime} \mathrm{E}\right)$. The specimen was identified by following the instructions of Froese and Pauly, 2017 [6]. The video was uploaded as an electronic reference and can be viewed online at https://youtu.be/F5SiYJ2K7Do

\subsection{Lophotus lacepede}

On 13 February 2017, a single specimen of Crested oarfish was photographed by amateur fisherman from Adrasan bay in Antalya (38 $1940^{\prime} \mathrm{N}, 2^{\circ} 1750^{\prime} \mathrm{E}$ ). The specimen was described following Golani et al. 2006 [5].

\section{Results and Discussion}

\section{Mola mola (Linnaeus, 1758)}

Systematics

Class: Actinopterygii

Family: Molidae Bonaparte, 1835

Genus: Mola Koelreuter, 1766

Mola mola (Linnaeus, 1758)

Diagnostic characteristics: Greatly huge body, elongated to sub-orbicular almost round and compressed. Ridged dorsal and anal fins in a vertical orientation. Caudal fin replaced with clavus and located between dorsal and anal fins. Skin thick and without scales.

Colour: Body silvery grey, brown on back.

Distribution: M. mola is considered as cosmopolitan species. However, it is reported mostly from the western Mediterranean and Atlantic ocean [7]. This paper reports its (Figure. 1) northernmost range as Hellenic and Turkish Aegean Sea $[8,9]$.

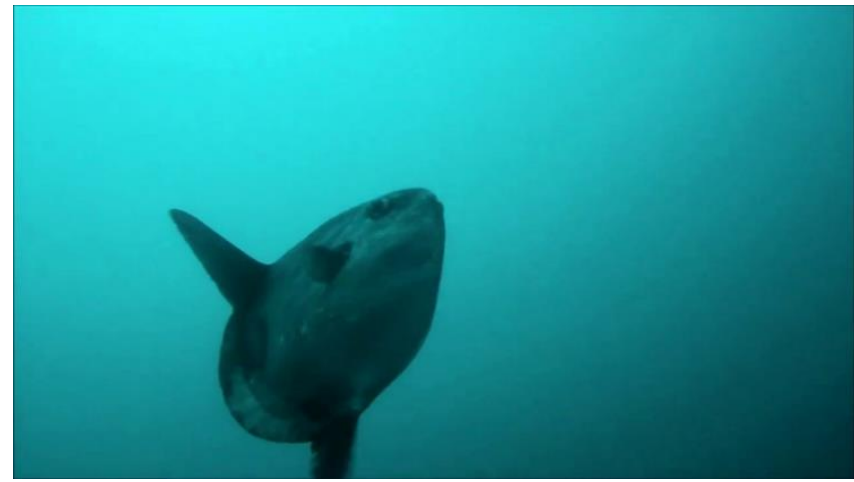

Figure 1. An underwater observation of Mola mola

\section{Ranzania laevis (Pennant, 1776)}

Systematics

Class: Actinopterygii

Family: Molidae Bonaparte, 1835

Genus: Ranzania Nardo, 1840

Ranzania laevis (Pennant, 1776)

Diagnostic characteristics: Elongated body covered with hexagonal plates, mouth almost vertical, caudal fin replaced with clavus, which includes 22 rays.

Colour: Body dorsally silvery blue, ventrally silvery grey. Distribution: Although $R$. laevis is classified as cosmopolitan species in all tropic and temperate oceans, it is very rare in the eastern Mediterranean [5]. This study represents its (Figure. 2) re-occurrence after the 1990s in eastern Mediterranean coasts of Turkey $[4,10,11]$.

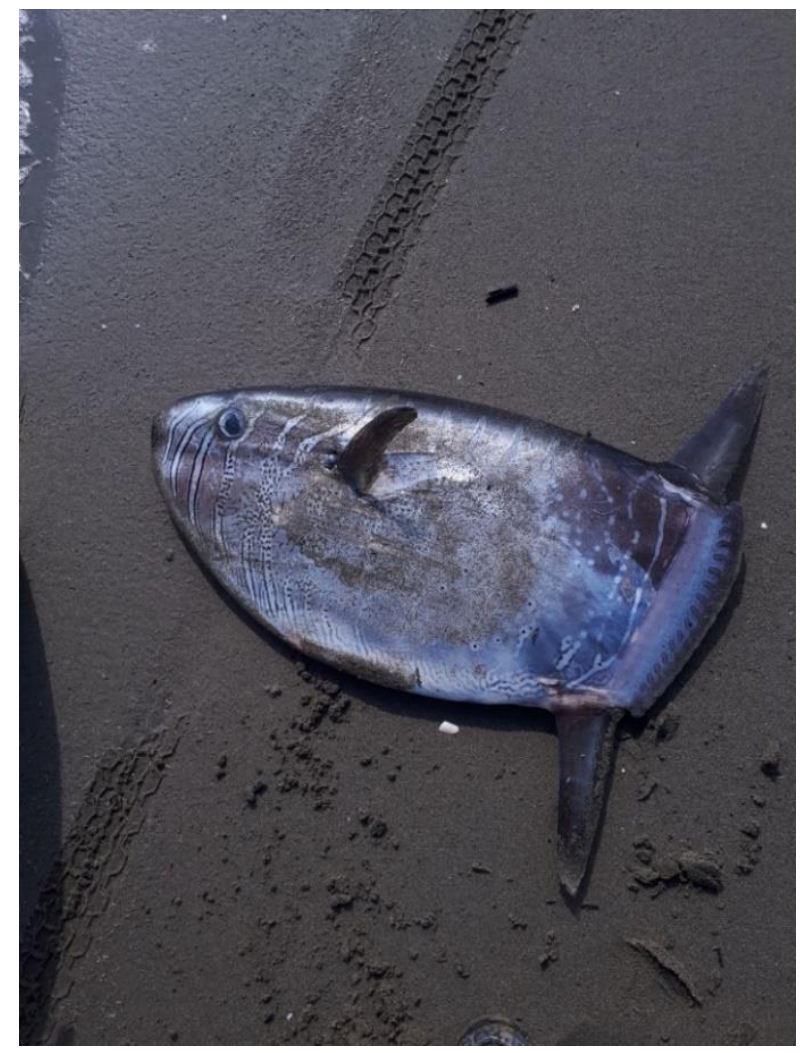

Figure 2. A general view of Ranzania laevis 


\section{Trachipterus trachypterus (Gmelin, 1789)}

Systematics

Class: Actinopterygii

Family: Trachipteridae Rafinesque, 1810

Genus: Trachipterus Goüan, 1770

Trachipterus trachypterus (Gmelin, 1789)

Diagnostic characteristics: Body elongate, compressed and greatest depth behind the head. Scales and anal fin absent. Caudal fin long, with an only upper lobe and oriented perpendicular to body. Pelvic fin rays are elongated in juveniles and small in adults. A very long dorsal fin, with origin well behind the tip of snout. Large eyes and teeth are exist.

Colour: Silvery in adults, lighter or transparent in juveniles. Characteristically 1-4 dark blotches over the lateral line - dorsum of head is purple in juveniles.

Distribution: T. trachypterus has been rarely reported in the Mediterranean [12,13,14] and Aegean Sea [15]. This study provides the first finding of its juvenile (Figure. 3) in the Turkish Aegean Sea.

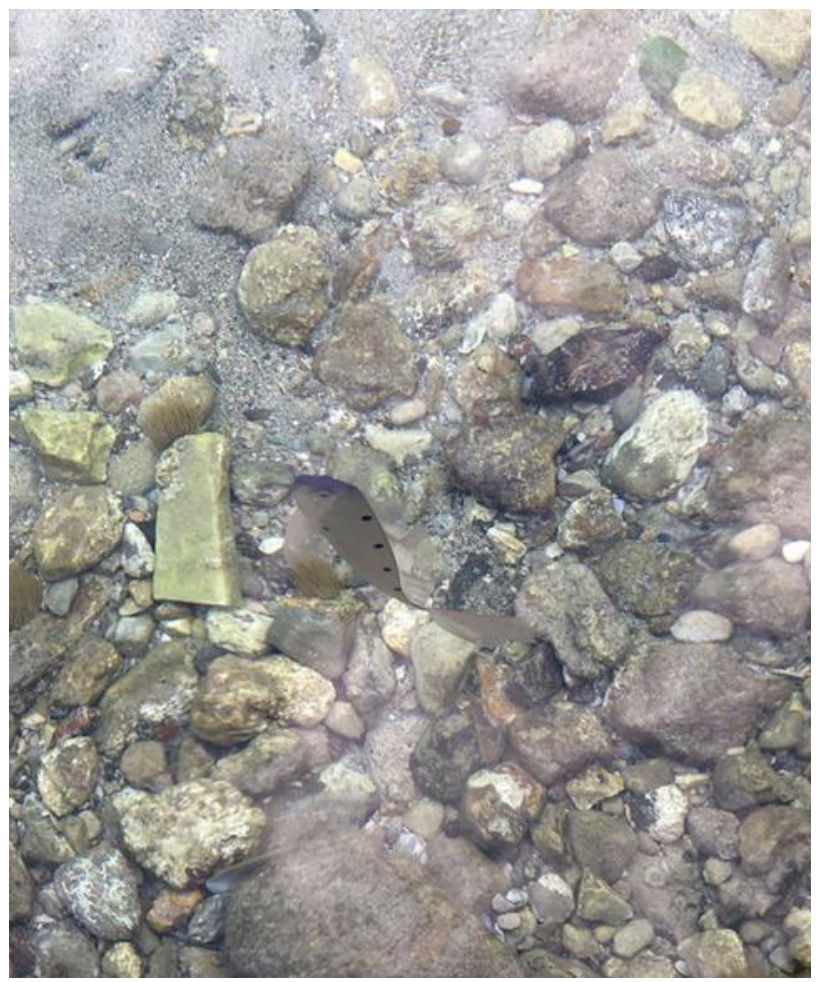

Figure 3. A general view of juvenile Trachipterus trachypterus

\section{Lophotus lacepede Giorna, 1809}

Systematics

Class: Actinopterygii

Family: Lophotidae Bonaparte, 1845

Genus: Lophotus Giorna, 1809

Lophotus lacepede Giorna, 1809

Diagnostic characteristics: Greatly compressed ribbonlike body tapering to the caudal fin and high occipital crest on the head. Scales cycloid and smooth plates on the lateral line. Dorsal fin extending along the dorsum of the body and its first ray is elongated. Anal fin located near caudal fin.

Colour: Dorsally blue body covered with brown and blue dots, but white in belly. Fins are red or pinkish.

Distribution: L. lacepede is considered as circumglobal. However, its distribution limited to the western Mediterranean, including Baleric Sea, Tyrrhenian Sea, Adriatic Sea and Aegean Sea [16]. This study is first to report and confirm the presence of L. lacepede (Figure 4) in the Turkish Levantine coasts.

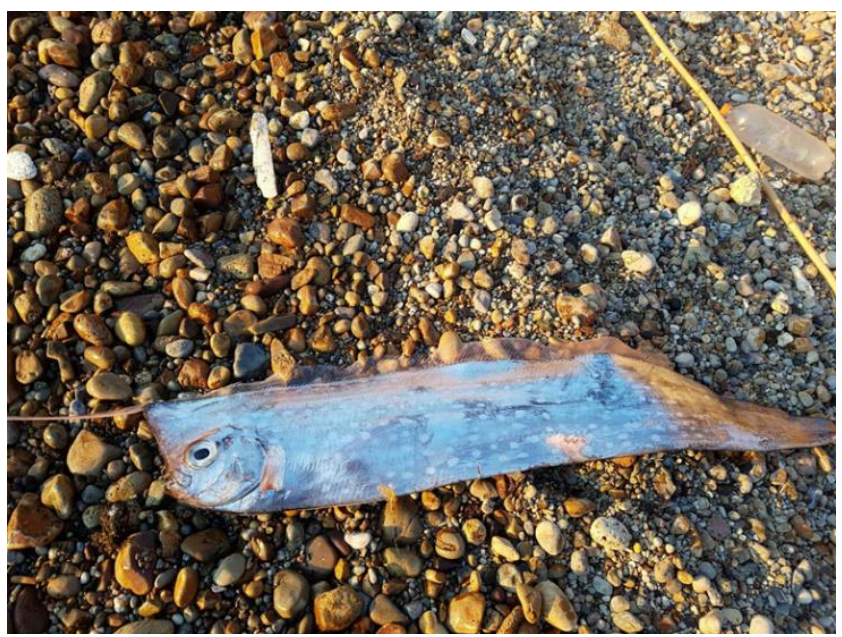

Figure 4. A general view of Lophotus lacepede

Semi-enclosed Mediterranean Sea is considered as the earth's biodiversity hotspots, because it has become a receiving marine environment for exotic species, showing high rates of endemism. Regrettably, the invasion rate of Mediterranean by such exotics has increased tremendously in recent years due to widening and deepening of Suez Canal, increased maritime traffic and increased spatial overlap between exotic and endemic ichthyofauna. Native species of the Mediterranean termed as "wide" could reach the neighboring Atlantic Ocean and Black Sea and may continue to survive by migrating northern sections or deeper water column. In contrast to them, the native species termed as "narrow" could not struggle for survival in new environmental conditions due to limits of their biological characteristics which reduce their capacity to adapt. Consequently, rare and endemic species can be good indicators of ecosystem health in the sense that their loss can result in homogenization of fauna and compromise ecosystem functioning.

The new and re-occurrence of exotic fishes are surprising, because they are found in unexpected locations with a subtropical climate. However, it should not be entirely interpreted as unfavorable steady-state ecosystem conditions in the sampling areas, because their distribution areas and abundance in the Aegean Sea and the Mediterranean are still unknown due to difficulties in sampling of cryptic and solitary individuals. They could easily be missed and have a much wider 
distribution than expected. Hence, their most current distribution always require further investigations.

\section{Acknowledgment}

The author would like to thank Prof. Dr. Halit Filiz, Namık Şahin and Denizhan Deniz for providing photos and to anonymous reviewers for their helpful and constructive comments.

\section{References}

[1] Azzurro, E. "The advance of thermophilic fishes in the Mediterranean Sea: overview and methodological questions", Climate warming and related changes in Mediterranean marine biota, Editor: Briand, F., CIESM Workshop Monographs, Monaco, 39- 46, 2008.

[2] Azzurro, E. "Unusual occurrences of fish in the Mediterranean Sea: an insight into early detection", Fish Invasions of the Mediterranean Sea: Change and Renewal, Editor: Golani, D. and Golani B.A., Pensoft Publishers, Sofia-Moscow, 99-126, 2010.

[3] Quignard, J.P. and Tomasini, J.A. "Mediterranean fish biodiversity" Biologia Marina Mediterranea, 7: 1-66, 2000.

[4] Bilecenoğlu, M., Kaya, M., Cihangir, M. and Çiçek, E., "An updated checklist of the marine fishes of Turkey", Turkish Journal of Zoology, 38: 901-929, 2014.

[5] Golani, D., Ozturk, B. and Basusta, N., "Fishes of the Eastern Mediterranean", Turkish Marine Research Foundation, Istanbul, Turkey, 2006.

[6] Froese, R. and Pauly, D. FishBase. Retrieved from: www.fishbase.org, 07 January 2017.

[7] Whitehead, P.J.P., Bauchot, M.L., Hureau, J.C., Nielsen, J. and Tortonese, E. "Fishes of the North-eastern Atlantic and the Mediterranean", Vol. I-III, Paris: UNESCO, 1986.

[8] Corsini-Foka, M. "Uncommon fishes from Rhodes and nearby marine region (SE Aegean Sea, Greece)", Journal of Biological Research-Thessaloniki, 12: 125133, 2009.

[9] Papaconstantinou, C. "Fauna Graeciae: An updated checklist of the fishes in the Hellenic Seas" Monographs on Marine Sciences, HCMR, 2014.

[10] Başusta, N., Erdem, Ü. and Genç, E. "İskenderun Körfezi'nde yakalanan Molidae türlerinin taksonomisi üzerine bir araştırma", III. Ekoloji ve Çevre Kongresi, Kırşehir, 1997.

[11] Başusta, N. and Erdem, Ü. "A Study on the Pelagic and Demersal Fishes of İskenderun Bay", Turkish Journal of Zoology, 24: 1-19, 2000.

[12] Borme, D. and Voltolina, F., "On the occurrence of ribbon fish Trachipterus trachtypterus (Gmelin, 1789 ) in the gulf of Trieste (Northern Adriatic Sea)" Annales Series Historia Naturalis., 16(2): 181-188, 2006.

[13] Psomadakis, P.N., Scacco, U. and Vacchi, M. "Recent findings of some uncommon fishes from the central Tyrrhenian Sea", Cybium, 30(4): 297-304.
[14] Tortonese, E. and Trotti, L. "Catalogo dei pesci del Mare Ligure". Centro Talassografico Tirreno, Pubbl. no. 1, Atti dell'Accademia Ligure di Scienze e Lettere, (1): 118, 1949.

[15] Caragitsou, E., Siapatis A., Anastasopoulou, A. and Papaconstantinou, C., "Seasonal distribution of ichthyoplankton in the Aegean", 5th Panhellenic Symposium on Oceanography and Fisheries, Kavala, NCMR, Athens, 1997, 143-145.

[16] Minos, G., Karidis, Y. and Economidis, P.S. "Range extension for crested oarfish Lophotus lacepede Giorna, 1809 in the waters of the northern Aegean Sea, Greece", Acta Adriatica, 56(2): 283-290, 2015. 